\title{
ANALISIS KORELASI DAN REGRESI ANTARA UKURAN-UKURAN TUBUH DENGAN BOBOT BADAN SAPI BRAHMAN CROSS (BX) BETINA DI KPT MAJU SEJAHTERA DESA TRIMULYO, KECAMATAN TANJUNG BINTANG, KABUPATEN LAMPUNG SELATAN
}

\author{
Analysis of Correlation and Regression between Body Measurements and Body Weight of Brahman \\ Cross (Bx) Cow in KPT Maju Sejahtera Trimulyo Village, Tanjung Bintang District, South Lampung \\ Regency
}

\section{Obet Yanto, M. Dima Iqbal Hamdani, Dian Kurniawati, Sulastri}

Department of Animal Husbandry, Faculty of Agriculture, Lampung University

Jl. Prof. Dr. Soemantri Bojonegoro No. 1 Gedong Meneng Bandar Lampung 35145 e-mail : obetyanto0@gmail.com

\begin{abstract}
This study aimed to determine the Correlation and the regression equation between body measurements and body weight of Brahman Cross (BX) Cow in KPT Maju Sejahtera Trimulyo village, Tanjung Bintang District, Lampung Selatan Regency. This research was conducted in July 2020. The data obtained were analyzed using simple and multiple regression analysis using the help of the Excel program. The material used in this study were 32 Brahman Cross (BX) Cow aged 2-3 years. The results of this study indicated that the average of Body Weight (BW), Chest Circumference (CC), Body Length (BL), and Shoulder height $(\mathrm{SH})$ were $472.66 \pm 53.59 \mathrm{~kg}, 179.95 \pm 7,95 \mathrm{~cm}, 132.49 \pm 6.39 \mathrm{~cm}, 127.95 \pm 3.08 \mathrm{~cm}$, respectively. The correlation value between $\mathrm{CC}, \mathrm{BL}, \mathrm{SH}$ with $\mathrm{BB}$ were $0.764,0.448$, and 0.551 , respectively. These results indicated that $\mathrm{CC}, \mathrm{BL}, \mathrm{SH}$, have a positive relationship with $\mathrm{BW}$. The regression equation resulting from the relationship between body weight and body size $\mathrm{CC}, \mathrm{BL}, \mathrm{SH}$ to $\mathrm{BW}$ with the value of determination $(\mathrm{R} 2)$ and significance $(\mathrm{P}<0.05)$ was $0.607(60.7 \%)$ with the regression equation $\mathrm{BW}=-674.003+4.314 \mathrm{CC}+1.247 \mathrm{BL}+1.602 \mathrm{SH}$.
\end{abstract}

Keywords: Brahman Cross, Body Measurement, Correlation and Regression

\begin{abstract}
ABSTRAK
Penelitian ini bertujuan untuk mengetahui korelasi dan persamaan regresi antara ukuran tubuh dengan bobot badan sapi BX Betina di KPT Maju Sejahtera Desa Trimulyo, Kecamatan Tanjung Bintang, Lampung Selatan pada Juli 2020. Data yang diperoleh dianalisis menggunakan korelasi sederhana dan regresi berganda dengan bantuan program Excel. Materi dalam penelitian menggunakan 32 ekor sapi BX Betina umur 2-3 tahun. Hasil penelitian ini menunjukkan rata-rata bobot badan (BB), Lingkar Dada (LD), Panjang Badan (PB), Tinggi Pundak (TP) masing-masing 25 sebesar 472,66 $\pm 53,59 \mathrm{~kg}, 179,95 \pm 7,95$ $\mathrm{cm}, 132,49 \pm 6,39 \mathrm{~cm}, 127,95 \pm 3,08 \mathrm{~cm}$. Nilai koefisien korelasi (r) menunjukkan bahwa LD, PB, TP dengan bobot badan masing-masing sebesar $0,764,0,448$, dan 0,551 . Hasil ini menunjukkan bahwa LD, PB, TP, memiliki hubungan positif terhadap BB. Persamaan regresi yang dihasilkan dari hubungan bobot badan dan ukuran-ukuran tubuh $\mathrm{LD}, \mathrm{PB}, \mathrm{TP}$ terhadap $\mathrm{BB}$ dengan nilai determinasi $\left(\mathrm{R}^{2}\right)$ dan signifikansi $(\mathrm{P}<0,05)$ yaitu $0,607(60,7 \%)$ dengan persamaan regresi $\mathrm{BB}=-674,003+4,314 \mathrm{LD}+1,247 \mathrm{~PB}+1,602$ TP.
\end{abstract}

Kata Kunci : Sapi Brahman Cross, Ukuran-ukuran Tubuh, Korelasi, dan Regresi

\section{PENDAHULUAN}

Seiring bertambahnya jumlah penduduk, pendapatan, perubahan pola konsumsi dan selera masyarakat menyebabkan konsumsi daging secara nasional terus meningkat. Pemenuhan konsumsi daging di Indonesia masih belum optimum karena populasi ternak pedaging khususnya ternak sapi masih sedikit dengan kondisi ternak yang kurang bagus terutama dalam hal pertumbuhan dan bobot badan. Salah satu ternak yang dapat dijadikan sebagai sumber protein hewani adalah ternak sapi potong. Salah satu jenis sapi potong yang banyak dikembangkan di Indonesia adalah sapi BX. 
Sapi BX merupakan ternak non- lokal yang berasal dari Australia dan mulai dibudidayakan oleh peternak di Indonesia. Impor pertama sapi BX terjadi pada tahun 1973. Penyebaran sapi BX secara besar- besaran di Indonesia terjadi tahun 2006 dalam rangka mendukung percepatan swasembada daging sapi nasional. Sapi BX dikembangkan di stasiun CSIRO's Tropical Cattle Research Centre Rockhampton Australia, dengan materi dasar sapi Brahman, Hereford dan Shorthorn dengan proporsi genetik berturut-turut 50\%, 25\%, dan 25\% (Turner, 1977).

Sapi Brahman Cross merupakan persilangan sapi Brahman dengan sapi Eropa (Firdausi et al., 2012). Tujuan dari persilangan ini utamanya adalah menciptakan bangsa sapi potong yang mempunyai produktivitas tinggi dan mempunyai daya tahan terhadap suhu tinggi, caplak, kutu, serta adaptif terhadap lingkungan tropis yang relatif kering.

Berdasarkan penentuan produksi sapi BX sebagai ternak pedaging, maka banyak hal yang harus diperhatikan. Salah satunya yaitu melalui penimbangan yang dilakukan untuk mengetahui bobot badan ternak tersebut. Data bobot badan sangat penting diketahui karena berguna dalam manajemen pemeliharaan ternak sapi potong dan tataniaga. Dalam manajemen pemeliharaan, bobot badan diperlukan untuk mengetahui kebutuhan pakan ternak dan mengetahui pertumbuhan ternak demi peningkatan produktivitas ternak, sedangkan dalam hal tataniaga, bobot badan berguna untuk menaksir harga ternak tersebut (Taylor, 1995).

Penimbangan terhadap bobot badan ternak terkadang dapat dimanipulasi oleh peternak atau pedagang yang seringkali melakukan kecurangan dengan memberikan pakan ataupun minum sebanyak mungkin untuk meningkatkan bobot badan ternak sebelum dijual. Oleh karena itu, perlu dilakukan pendugaan bobot badan melalui ukuran-ukuran tubuh ternak untuk mengetahui bobot badan ternak yang sesungguhnya. Ukuranukuran tubuh ternak yang meliputi panjang badan, lingkar dada, dan tinggi pundak menjadi penting karena diketahui bahwa ukuran- ukuran tubuh tersebut sangat berkorelasi dengan bobot badan ternak. Selain itu, pendugaan bobot badan dengan ukuran- ukuran tubuh tersebut sangat efisien dan akurat.

\section{MATERI DAN METODE}

Penelitian ini dilaksanakan pada Juli 2020 di KPT Maju Sejahtera Desa Trimulyo, Kecamatan Tanjung Bintang, Kabupaten Lampung Selatan. Peralatan yang digunakan adalah timbangan digital merk Warwick Cattle Crush kapasitas 2 ton dan pita ukur rondo ketelitian $0,1 \mathrm{~cm}$. Bahan yang digunakan dalam penelitian ini menggunakan sapi BX Betina 32 ekor. Metode yang digunakan dalam penelitian ini adalah metode penelitian survey dengan pengambilan data secara sensus. Pengambilan data dilakukan secara langsung dengan mengukur ukuran-ukuran tubuh dan menimbang sapi. Penelitian ini menggunakan data yang diperoleh dari pengukuran panjang badan, lingkar dada, tinggi pundak, dan penimbangan bobot tubuh sapi.

\section{Analisis Data}

Data yang diperoleh dianalisis menggunakan korelasi dan regresi sederhana dan berganda dengan bantuan program Excel.

\section{HASIL DAN PEMBAHASAN}

\section{A. Bobot Badan dan Ukuran-ukuran tubuh Sapi BX}

Berdasarkan penelitian yang telah dilakukan, diperoleh rata-rata bobot badan dan ukuran-ukuran tubuh yang meliputi lingkar dada, panjang badan, dan tinggi pundak yang disajikan pada Tabel 1.

Tabel 1. Rata-rata bobot badan dan ukuran-ukuran tubuh sapi BX di KPT Maju Sejahtera Desa Trimulyo Kabupaten Lampung Selatan

\begin{tabular}{lllll}
\hline Variabel & Rataan & Median & Minimum & Maksimum \\
\hline Bobot Badan (kg) Lingkar & $472,66 \pm 53,59$ & 471,50 & 373,00 & 584,00 \\
Dada (cm) Panjang Badan & $179,95 \pm 7,95$ & 181,50 & 163,33 & 193,33 \\
$(\mathrm{~cm})$ & $132,49 \pm 6,39$ & 132,67 & 120,33 & 145,33 \\
Tinggi Pundak $(\mathrm{cm})$ & $127,95 \pm 3,08$ & 128,67 & 119,33 & 133,67 \\
\hline
\end{tabular}


Rata- rata bobot badan sebesar $472,66 \pm 53,59$, dengan median 471,50 dengan bobot minimum sapi $373,00 \mathrm{~kg}$ dan bobot maksimum sebesar $584,00 \mathrm{~kg}$. Bobot tubuh ternak merupakan hasil pengukuran dari proses tumbuh ternak yang dilakukan dengan cara penimbangan (Tillman et al., 1998). Bobot badan dan ukuran-ukuran tubuh memiliki keterkaitan yang erat, terlebih panjang badan dan lingkar dada sering digunakan menjadi parameter dalam pendugaan bobot badan ternak, terkhusus peternak yang tidak mempunyai timbangan. Aberle et al. (2001) menyatakan bahwa pertumbuhan dapat dinilai sebagai peningkatan tinggi, panjang badan, ukuran lingkar dada dan bobot badan yang terjadi pada seekor ternak muda yang sehat serta diberi pakan, minum dan mendapat tempat berlindung yang layak.

Rata-rata panjang badan $132,49 \pm 6,39$ $\mathrm{cm}$, dengan median sebesar $132,67 \mathrm{~cm}$, dan data terkecil diperoleh sebesar 120,33 cm serta data terbesar atau maksimum diperoleh $145,33 \mathrm{~cm}$. Panjang badan dapat digunakan untuk melakukan pendugaan bobot tubuh ternak karena memiliki pengaruh terhadap pertumbuhan tulang khususnya tulang belakang. Secara normal panjang badan yang semakin panjang maka akan menghasilkan bobot tubuh yang semakin meningkat pula (Anggorodi, 1979).

Rata-rata lingkar dada pada penelitian ini sebesar 179,95 7,95 dengan median sebesar $181,50 \mathrm{~cm}$, data terkecil lingkar dada $163,33 \mathrm{~cm}$ dan data tertinggi pada lingkar dada 193,33 cm. Besar kecilnya lingkar dada sangat berpengaruh terhadap besar kecilnya berat badan seekor ternak. Pertambahan lingkar dada dapat menyebabkan bertambahnya bobot badan, dimana daerah badan akan semakin dalam dan meluas yang akhirnya bagian tersebut akan tertimbun oleh otot, daging maupun lemak. Penimbunan otot ini akan mempengaruhi perubahan badan yang semakin membesar dan bertambah berat (Sudarmono dan Sugeng, 2008).

Rata-rata tinggi pundak pada penelitian ini sebesar 127,95 $\pm 3,08 \mathrm{~cm}$ dan median 128,67 $\mathrm{cm}$ dengan rentang data terkecil 119,33 cm dan data tertinggi sebesar 133,67 $\mathrm{cm}$. Tinggi pundak juga merupakan salah satu ukuran tubuh yang dapat digunakan sebagai data pendukung dalam identifikasi performa ternak. Ni'am et al. (2012) menyatakan tinggi pundak dengan bobot badan memiliki keeratan hubungan yang semakin meningkat seiring dengan bertambahnya umur. Tillman et al. (1998) menyatakan pertumbuhan tulang akan meningkat pada laju pertumbuhan awal, kemudian akan diikuti dengan perkembangan dan terakhir dengan adanya kandungan energi pakan yang diberikan, maka lemak akan mengalami peningkatan pesat. Rahayu (2003) menyatakan bahwa pertumbuhan tulang mulai melambat pada sapi usia 2 tahun (dewasa tubuh) dan akan terhenti di usia 2,5 tahun

\section{B. Korelasi antara Bobot Badan dengan Ukuran-ukuran tubuh Sapi BX}

Berdasarkan penelitian yang telah dilakukan ditunjukkan pada Tabel 2, didapatkan hasil yang menunjukkan terdapat korelasi yang positif antara ukuran-ukuran tubuh terhadap bobot badan sapi BX.

Tabel 2. Korelasi antara bobot badan dengan ukuran-ukuran tubuh sapi BX di KPT Maju Sejahtera Desa Trimulyo Kabupaten Lampung Selatan

\begin{tabular}{llll}
\hline $\begin{array}{l}\text { Korelasi antar } \\
\text { Variabel }\end{array}$ & $\begin{array}{l}\text { Koefisien } \\
\text { Korelasi }(\mathrm{r})\end{array}$ & Tingkat Korelasi & $\begin{array}{l}\text { Keterangan } \\
\text { Signifikansi }(\mathrm{P}<0,05)\end{array}$ \\
\hline Korelasi sederhana & & & Signifikan \\
\hline BB - LD & 0,764 & Kuat & Signifikan \\
BB - PB & 0,448 & Sedang & Signifikan \\
BB - TP & 0,551 & Sedang & P
\end{tabular}

Keterangan $: \mathrm{LD}=$ Lingkar Dada, $\mathrm{PB}=$ Panjang Badan, $\mathrm{TP}=$ Tinggi Pundak $\mathrm{BB}=\mathrm{Bobot}$ Badan $\mathrm{BB}=$ Bobot Badan

Dapat dilihat bahwa ukuran- ukuran tubuh memiliki korelasi terhadap bobot badan, hal ini dapat dilihat dari nilai koefisien korelasi $r$ masing-masing lingkar dada, panjang badan, dan tinggi pundak sebesar 0,764, 0,448, dan 0,551. Panjang badan dengan bobot badan dan tinggi pundak dengan bobot badan pada penelitian ini memiliki korelasi sedang dan pada lingkar dada dengan bobot badan memiliki korelasi kuat.

Hal ini berdasarkan pendapat Sugiyono (2013), bahwa nilai korelasi 0,60-

$-0,799$ termasuk dalam kategori kuat dan nilai korelasi 0,40--0,599 termasuk dalam kategori 
sedang. Yusuf (2004) yang menyatakan bahwa, secara fisiologis lingkar dada memiliki pengaruh yang besar terhadap bobot badan karena dalam rongga dada terdapat organ-organ seperti jantung dan paru-paru. Organ-organ tersebut akan tumbuh dan mengalami pembesaran sejalan dengan pertumbuhan ternak. Selain itu, pertambahan bobot badan juga akan dipengaruhi oleh penimbunan lemak.

Hasil penelitian ini yang memiliki nilai korelasi paling tinggi yaitu hubungan antara lingkar dada dan bobot badan dengan nilai korelasi 0,764 . Korelasi yang tinggi antara lingkar dada dan bobot badan juga ditunjukkan oleh penelitian Ikhsanuddin et al. (2018) pada sapi sapi Aceh umur 365 hari menunjukkan koefisien korelasi antara lingkar dada dengan bobot badan sebesar 0,68.

Korelasi antara panjang badan dengan bobot badan menunjukkan koefisien korelasi sebesar 0,448 menunjukan hubungan yang nyata $(\mathrm{P}<0,05)$. Hal ini menunjukkan apabila terjadi kenaikan panjang badan akan terjadi kenaikan bobot badan. Secara normal panjang badan yang semakin panjang maka akan menghasilkan bobot tubuh yang semakin meningkat pula (Anggorodi, 1979). Hasil penelitian ini tidak berbeda jauh dengan penelitian Ikhsanuddin et al. (2018) pada 159 ekor sapi Aceh berumur 1 tahun dengan koefisien korelasi sebesar 0,58. Secara normal, panjang badan yang semakin panjang maka akan menghasilkan bobot tubuh yang akan meningkat. Tingginya korelasi antara sifat pertumbuhan seperti bobot badan dengan ukuran tubuh menunjukkan bahwa secara umum bobot tubuh dipengaruhi oleh beberapa gen yang sama dan seleksi terhadap satu sifat akan meningkatkan sifat yang lainnya (Maiwasha et al., 2002).

Hal ini juga dapat dipengaruhi oleh faktor-faktor pertumbuhan seperti genetik, umur, lingkungan, pakan, dan manajemen. Pola pertumbuhan pada sapi secara umum berpola sigmoid, yaitu pertumbuhan dari awal sapi dilahirkan kemudian pase percepatan pertumbuhan sampai mencapai titik infleksi atau sampai mencapai umur pubertas, selanjutnya ternak mencapai dewasa tubuh. Pada fase ini mulai terjadi perlambatan pertumbuhan sampai pertumbuhan relatif konstan (Tazkia dan Anggraeni, 2009).
Korelasi antara tinggi pundak dengan bobot badan menunjukkan hasil dengan nilai koefisien korelasi sebesar 0,551 menunjukan hubungan yang nyata $(\mathrm{P}<0,05)$. Hal ini menunjukkan apabila terjadi kenaikan tinggi pundak akan terjadi kenaikan bobot badan. Ni'am et al. (2012) menyatakan tinggi pundak dengan bobot badan memiliki keeratan hubungan yang semakin meningkat seiring dengan bertambahnya umur.

Hasil penelitian ini memiliki hubungan yang sedang dikarenakan faktor tinggi pundak terhadap bobot badan tidak dominan, karena tinggi pundak berkaitan dengan pertumbuhan tulang kaki, menurut pendapat Rahayu (2003) bahwa pertumbuham tulang mulai melambat pada sapi usia 2 tahun (dewasa tubuh) dan akan terhenti di usia 2,5 tahun, sedangkan bobot badan akan selalu mengalami pertambahan bobot badan dikarenakan adanya penumpukan lemak yang membuat bobot badan naik, hal ini sesuai pendapat Yusuf (2004) menyatakan secara fisiologis pertambahan bobot tubuh dipengaruhi faktor penimbunan lemak.

\section{B. Persamaan Regresi antara Ukuran- ukuran tubuh dengan bobot badan Sapi BX}

Pada Tabel 3 menunjukkan secara berturut-turut persamaan regresi antara bobot badan dengan ukuran-ukuran tubuh yaitu : $\mathrm{BB}=-674,003+4,314 \mathrm{LD}+1,247 \mathrm{~PB}+1,602$ $\mathrm{TP}$, dengan koefisien determinasi (R2) sebesar 0,607 , artinya $60,7 \%$ bobot badan dipengaruhi oleh faktor panjang badan, lingkar dada, dan tinggi pundak, dan sisanya dipengaruhi oleh faktor lain. Persamaan regresi tersebut dapat dijadikan sebagai pendugaan bobot badan.

Berdasarkan persamaan regresi tersebut, apabila terjadi pertambahan $1 \mathrm{~cm}$ lingkar dada maka diikuti dengan pertambahan 4,314 $\mathrm{kg}$ bobot badan dengan mengabaikan panjang badan dan tinggi pundak dan apabila terjadi pertambahan $1 \mathrm{~cm}$ panjang badan maka akan diikuti dengan pertambahan $1,247 \mathrm{~kg}$ bobot badan dengan mengabaikan lingkar dada dan tinggi pundak, dan apabila terjadi pertambahan $1 \mathrm{~cm}$ tinggi pundak maka akan diikuti $1,602 \mathrm{~kg}$ bobot badan dengan mengabaikan lingkar dada dan panjang badan, apabila panjang badan, lingkar dada, dan tinggi pundak secara bersamaan adalah 0 maka bobot badan $-674,003$. 
Tabel 3. Persamaan regresi ukuran-ukuran tubuh terhadap bobot badan sapi BX di KPT Maju Sejahtera Desa Trimulyo Kabupaten Lampung Selatan

\begin{tabular}{|c|c|c|c|}
\hline $\begin{array}{c}\text { Ukuran Tubuh dengan } \\
\text { Bobot Badan }\end{array}$ & $\begin{array}{c}\text { Persamaan } \\
\text { Regresi }\end{array}$ & $\begin{array}{c}\text { Nilai } \\
\text { Determinasi } \\
\left(\mathrm{R}^{2}\right)\end{array}$ & $\begin{array}{c}\text { Keterangan } \\
\text { Signifikansi }(\mathrm{P}<0,05)\end{array}$ \\
\hline Lingkar Dada & $\mathrm{BB}=-454,889+5,154 \mathrm{LD}$ & 0,585 & 0,000000343 \\
\hline Panjang Badan & $\mathrm{BB}=-25,321+3,758 \mathrm{~PB}$ & 0,200 & 0,010103128 \\
\hline Tinggi Pundak & $\mathrm{BB}=-755,835+9,601 \mathrm{TP}$ & 0,303 & 0,00107378 \\
\hline $\begin{array}{l}\text { Lingkar Dada+Panjang } \\
\text { Badan }\end{array}$ & $\begin{array}{c}\mathrm{BB}=-540,519+4,731 \mathrm{LD} \\
+1,220 \mathrm{~PB}\end{array}$ & 0,602 & 0,00000155 \\
\hline $\begin{array}{l}\text { Lingkar Dada+Tinggi } \\
\text { Pundak }\end{array}$ & $\begin{array}{c}\mathrm{BB}=-575,847+4,779 \mathrm{LD} \\
+1,472 \mathrm{TP}\end{array}$ & 0,589 & 0,00000250 \\
\hline $\begin{array}{l}\text { Panjang Badan+Tinggi } \\
\text { Pundak }\end{array}$ & $\begin{array}{l}\mathrm{BB}=-934,193+2,758 \mathrm{~PB} \\
+8,139 \mathrm{TP}\end{array}$ & 0,405 & 0,000537117 \\
\hline $\begin{array}{l}\text { Lingkar Dada+Panjang } \\
\text { Badan+Tinggi Pundak }\end{array}$ & $\begin{aligned} \mathrm{BB}= & -674,003+4,314 \mathrm{LD} \\
& +1,247 \mathrm{~PB}+1,602 \mathrm{TP}\end{aligned}$ & 0,607 & 0,000007195 \\
\hline
\end{tabular}

Keterangan : LD = Lingkar Dada $(\mathrm{cm}), \mathrm{PB}=$ Panjang Badan $(\mathrm{cm}), \mathrm{TP}=$ Tinggi Pundak $(\mathrm{cm}), \mathrm{BB}=$ Bobot Badan.

Hasil analisis regresi berganda pada penelitian ini hampir sama dengan hasil penelitian Ikhsanuddin et al. (2018) hasil analisis regresi berganda menunjukkan bahwa pada sapi Aceh umur 365 hari, nilai koefisien determinasi pada lingkar dada, panjang badan dan tinggi pundak masing- masing adalah $\mathrm{BB}=$ $44,96+0,72 \mathrm{LD}+0,47 \mathrm{~PB}+0,24 \mathrm{TP}$ dengan nilai determinasi $\left(R^{2}\right) 0,57$. Lingkar dada paling tinggi dibandingkan panjang badan dan tinggi pundak. Hal ini menunjukkan bahwa variabel lingkar dada memberikan pengaruh lebih besar terhadap bobot tubuh dibandingkan variabel panjang badan dan tinggi pundak. Hasil persamaan regresi menggambarkan bahwa lingkar dada memiliki pengaruh paling besar diantara panjang badan dan tinggi pundak terhadap peningkatan ataupun penurunan bobot badan.

Berdasarkan Tabel 3 persamaan yang menggunakan kombinasi lingkar dada dan panjang badan $\mathrm{BB}=-540,519+4,731 \mathrm{LD}+$ 1,220 PB adalah yang tertinggi dari kombinasi lingkar dada dan tinggi pundak terhadap bobot badan dan kombinasi panjang badan dan tinggi pundak terhadap bobot badan, dengan koefisien determinasi $\left(R^{2}\right)$ 0,602 artinya $60,2 \%$ panjang badan dan lingkar dada mempengaruhi bobot badan. Persamaan yang menggunakan kombinasi lingkardada dan tinggi pundak $\mathrm{BB}=$
$-575,847+4,779 \mathrm{LD}+1,472 \mathrm{TP}$ dengan koefisien determinasi $\left(\mathrm{R}^{2}\right)$ 0,589 artinya 58,9\% bobot badan dipengaruhi oleh lingkar dada dan tinggi pundak dan sisanya faktor lain. Persamaan yang menggunakan kombinasi antara panjang badan dan tinggi pundak $\mathrm{BB}=-934,193+2,758$ $\mathrm{PB}+8,139$ TP.

Hal ini cukup menjelaskan bahwa ukuran-ukuran tubuh memberikan pengaruh yang signifikan terhadap peningkatan bobot badan sapi BX. Nilai determinasi yang tertinggi pada penelitian ini adalah lingkar dada dengan koefisien determinasi 0,585 yang artinya $58,5 \%$ lingkar dada mempengaruhi peningkatan bobot badan dan yang terkecil adalah panjang badan dengan koefisien determinasi 0,200 yang artinya panjang badan hanya $20 \%$ mempengaruhi peningkatan bobot badan yang $80 \%$ adalah faktor lain, Hal ini menunjukkan bahwa variabel lingkar dada memberikan pengaruh lebih besar terhadap bobot badan dibandingkan variabel panjang badan dan tinggi pundak.

\section{KESIMPULAN DAN SARAN}

Kesimpulan

1. Lingkar dada, panjang badan, dan tinggi pundak memiliki korelasi positif dengan bobot badan sapi BX secara berturut-turut yaitu sebesar 0,764 (berkorelasi kuat), 0,448, dan 0,551 (sedang). 
2. Terdapat persamaan regresi yang dihasilkan dari hubungan bobot badan dengan lingkar dada, panjang badan, dan tinggi pundak adalah $\mathrm{BB}=-674,003+$ 4,314 $\mathrm{LD}+1,247 \mathrm{~PB}+1,602 \mathrm{TP}$ dengan koefisien determinasi $\left(\mathrm{R}^{2}\right)$ sebesar 0,607

\section{Saran}

Berdasarkan hasil persamaan regresi dan adanya korelasi antara ukuran- ukuran tubuh dengan bobot badan maka disarankan untuk menduga bobot ternak melalui ukuran ukuran tubuh dapat menggunakan lingkar dada, panjang badan, dan tinggi pundak

\section{DAFTAR PUSTAKA}

Aberle E. D., J. C. Forrest, D. E. Gerrard, E. W. Mills, H. B. Hendrick, M. D. Judge \& R. A. Merkel. 2001. Principles of Meat Science. 4th Ed. Kendall/Hunt Publishing Co., Iowa.

Anggorodi, R.1979. Ilmu Makanan Ternak Umum. PT Gramedia.Jakarta.

Firdausi A, T.Susilowati, M. Nasich,dan Kuswati. 2012. Pertambahan bobot badan harian Sapi Brahman Cross pada bobot badan dan frame size yang berbeda. Jurnal Ternak Tropika. 13(1):48--62.

Ikhsanuddin., V. M. A. Nurgiartiningsih, Kuswati, dan Zainuddin. 2018. Korelasi ukuran tubuh terhadap bobot badan Sapi Aceh umur sapih dan umur satu tahun. Jurnal Agripet. 18(2):117--122.

Maiwasha, A. N. M., J. Bradfield, H. E. Theron, and J. B. Van Wyk. 2002. Genetic parameter estimates for body measurements and growth traits in south african bonsmara cattle. Livest. Prod. Sci. 75:293-300.

Ni'am, H. U. M., A. Purnomoadi dan S. Dartosukarno. 2012. Hubungan antara bobot badan sapi Bali betina pada berbagai kelompok umur.

Rahayu, B. S. T. 2003. Studi bobot badan dan ukuran-ukuran tubuh sapi Pesisir di Kabupaten Pesisir Selatan dan Padang Pariaman Sumatera Barat. Skripsi. Fakultas Peternakan IPB. Bogor.

Sudarmono, A. S. dan Y. B. Sugeng. 2008. Sapi Potong : Edisi Revisi. Penebar Swadaya. Jakarta.

Sugiyono. 2013. Metode Penelitian Kuantitatif Kualitatif dan R\&D. Alfabeta. Bandung.
Taylor, R. E. 1995. Scientific Farm Animal Production. An Introduction Animal Science, Fifth Edition. Prentice-Hall Inc. New Jersey.

Tazkia R, A. Anggraeni. 2009. Pola dan estimasi kurva pertumbuhan sapi FriesianHolstein di wilayah kerja bagian timur Kpsbu Lembang. Departemen Ilmu Produksi dan Tekologi Peternakan, Fakultas Peternakan, IPB. Bogor

Tillman, A. D., H. S. Hartadi. S. Reksohadiprojo, Prawirokusumo. Dan S. Lebdosoekojo. 1998. Ilmu Makanan Ternak Dasar. Edisi Keenam. Gadjah Mada University Press. Yogyakarta.

Turner, H. G. 1977. The tropical adaptation of beef cattle. an Australian study. In: animal breeding: selected articles from the word anim. Rev. FAO Animal Production and Health Paper. 1:92-97

Yusuf, M. 2004. Hubungan antara Ukuran Tubuh dengan Bobot Badan Sapi Bali di Daerah Bima NTB. Skripsi. Universitas Gadjah Mada, Yogyakarta 